\title{
The Doctrine of Non-Retroactivity of International Treaties.
}

\author{
João Grandino Rodas \\ Assistent Professor Doctor of International \\ Law at University of São Paulo Law School
}

1. Introduction. 2. Necessity, Nature, Basis and Value of the Principle of Non-Retroactivity. 3. The principle of Non-Retroactivity and the International Treaties. 4. The Retroactivity of Interpretation. 5. The International Judge or Arbiter and the principle of non-retroactivity. 6. Attitude of the International Judge or arbiter in the face of the non-retroactivity of convention. 7. The non-retroactivity and the international law commision. 8. "Jus Cogens" and Non-retroactivity. 9. The question of non-retroactivity of ratification to the time of signature. A. The North-American Doctrine. B. Reaction to the American Doctrine.

\section{Introduction.}

Public International Law is deeply imbedded in time. It bears the influences of changes in international relations and its action happens in time and space.

The time factor in Public International Law has three forms: the instant, the duration and the change.

The instant is taken in consideration to determine the moment or the date in which a fact produces certain effects.

All legal system have institutions that are grounded in the second element - the duration. In International Law, this notion is less rigorous than in the municipal law, 
nevertheless there is a great deal of delays: delay of procedure, delay of appeal, etc.

The third form is the change. The circumstances change may influence the rules and transform law.

The question of application of rules in time arises from changes in the law. When the law changes, it is necessary to circumscribe the field of application of the past and of the new law. This delimitation is the task of the intertemporal law, which largely depends of the solution given to the problem of the division of time.

Although time is fluent, we are used to dividing it in moments: past, present and future. This causes difficulties, since the division of time is arbitrary.

Three ways of possible action of rule in time correspond to three moments of time fluency. The rule's action may refer to the past. In this case, we will have retroactive effect. Relating to the present, it will become immediatly effective. If the action refers to the future, we will have postponed effect.

Three theories were proposed to settle the problems of conflict of law in time: The theory of causes, the theory of rights and the theory of facts and situations.

In the first theory we must examine if there was a final judiciary decision, discerning the past causes, the causes in operation and the future causes ("causae finitae, pendentes et futurae").

In the second theory, we ought to look for an acquired right ("jura quaesita"). There will be retroactivity if it affects acquired rights. One must distinguish between acquired rights and the non-acquired rights or rights in course of acquisition.

In the latter theory the action of the rule will be defined in connection with facts and legal situations. The existence of past, pendent, in course or future action ("facta praeterita, pendentia et futura") will have to be established. 
The theory of causes is less employed in Public International Law than in municipal law due to the smaller number of judiciary or arbitrary decisions.

Besides the respect toward the "causae finitae", the retroactivity is sometimes attenuated by the grant of delays that makes easy the application of the new law. The new rule may decide that a past fact did not have enough power to produce certain situations, but the past effects of these situations will be respected - temperate retroactivity.

The retroactivity's notion is not monolithic, since it's present on several forms.

The retroactivity is only one of the three positions of a rule in time and questions of time do not limit themselves to problems of non-retroactivity.

\section{Necessity, Nature, Basis and Value of the Principle of Non-retroactivity.}

The questions of necessity nature, basis and value of the principle of non-retroactivity in Public International Law have not been discussed yet by the doctrine and were only lighty touched by jurisprudence.

Charles Rousseau and BaAde recognize the necessity of the principle of non-retroactivity, though they admit that this principle has certain limits. However other internationalists doubt such necessity. Some italian jurists - as CAVAGLIERI for instance - deny the possibility of a transitory law in International Law and consequently reject the existence of a principle of non-retroactivity.

The principle of non-retroactivity was concerned by municipal legislations. This principle was introduced by the constituent or normal legislator or by jurisprudence. The the principle of non-retroactivity is liable to be con sidered as a "general principle of law recognized by civi- 
lized nations" in the sense of art. $38 \S 1$ of the Statute of the International Court of Justice.

The principle of non-retroactivity of international rules was approved by the conventional practice, by the practice of International Organizations and by the International judges and arbiters. Nevertheless, this principle was deemed expressly as a general principle.

From the legal technical point of view the problems arisen from the principle of non-retroactivity are essencially the same both in municipal and international law. This is due to the fact that the basis are the same in the two cases.

The essential basis of the principle of non-retroactivity in Public International Law and in municipal law results from the necessity to assure the security of legal relations. These basis are not accepted unanimously. The adherents of the new laws application, for extralegal or political reasons, often invoke the imperatives of progress against the principle of non-retroactivity. As a matter of fact, the necessity of adaptability of law to the variable conditions on international relations, under certain circumstances, requires that to the adaptabilit be superposed the necessity of security.

The principle of non-retroactivity in Public Internationa Law is not an absolute principle, since it must consider certain external effects.

The principle of non-retroactivity does not have the same value in all cases. The practice admits that the treaties and conventions may derogate it expressly or even tacitly. Nevertheless, this principle has a superior value regarding treaties in the sense that the exceptions to this principle must be interpreted restrictively. The introduction in Public International Law of the notion of "Jus Cogens" puts the problem of value of the principle of non-retroactivity in connection with "Jus Cogens". It seems 
that the Commission gave to the "Juris Cogentis" rules certain consequences that turn true to the past.

\section{The Principle of Non-retroactivity and the International Treaties.}

Tavernier made a statistical and systematic search about treaties signed by States and International Organizations with a view to extracting from numerous international conventions the principle of non-retroactivity.

He adopted the most general definition of retroativity:

The retroactivity results from the anteriority of the coming into effect of the signature of the treaty, and from the anteriority of the date of the effects in regard to the entry into force. The date of entry into force and the date of signature may sometimes be the same.

He arrived at the folloving conclusions:

1 - It is extremely rare to find non-retroactivity expressly stipulated in the conventions;

2 - The number of retroactive treaties among the treaties examined is very small less than $10 \%$.

This means that non-retroactivity is the rule and retroactivity the exception.

The reasons which seem to have led the States to stipulate the retroactivity are chiefly the interpretative or complementary character of the convention or the necessity of regulating a situation arisen before the treaty. It seems that the last one is the principal reason for retroactivity of treaties and which may be subdivided into the following:

1 - The States want to fill a legal gap - a situation of fact grown an applicable legal rule.

2 - The retroactivity is due to the desire to avoid the break of continuity in the application of legal rules. 
3 - The retroactivity is stipulated by the contracting States in order to permit the harmonization of the time application of legal rules belonging to different legal orders, but which governs the same situation or are contained in separate conventions, notwithstanding the connected rule situations.

4 - Retroactivity is stipulated to regulate certain situations that without it would be against the law. One can still find the retroactivity adjusted for technical reasons or accidentaly, when it results from the terms of the agreement without the will of the parties.

Since the retroactivity results frequently from an express clause or particular reason, the rule is the non-retroactivity of the treaties and conventions.

\section{The retroactivity of interpretation.}

According to Rousseau an interpreted rule is not a new rule and can therefore be retroactive.

In the Chamizal Case between United States and Mexico, the comission refuted the Mexican thesis of non-retroactivy saying that the interpretative treaties or conventions are applied retroactively.

In the Sambiaggio Case "The Umpire concludes that the interpretation of the old treaty in article VIII of the Protocol has no retroactive effect and no reference to pending arbitrations". This sentence does not contradict the principle of retroactive effect on interpretative conventions, since the protocol of 1903 in spite of its terms did not express an interpretative rule of the 1861 treaty but a new one.

The interpretation's retroactivity is admitted by doctrine and by jurisprudence. The PaIJ, in the German Minority Schools in Upper Silesia Case, referring to the interpretation of articles 74 and 131 of the German-Polish Convention (May 15th, 1922) says: 
"... in accordance with the rules of law, the intepretation given by the Court to the terms of the Convention has retrospective effect - in the sense that terms of the convention must be held to have always borne the meaning placed upon them by this interpretation. ."

Its is characteristic of the authentic interpretation either judiciary or conventional - that its effects go back to the time when the rule interpreted appeared. This retroactivity is an exception that confirms the rule on non-retroactivity.

The cases of conventional retroactivity explainable by the principle of autonomy of the will are also exceptions to the rule of non-retroactivity.

\section{The international judge or arbiter and the principle of non-retroactivity.}

The international judge or arbiter tends to stay clear as far as possible, from questions of intertemporal law. This tendency is not peculiar to Public International Law, since it can be found also in municipal law.

The judge, faced with a problem of retroactivity, is liable to adopt three attitudes: 1 - to pass it over; 2 not to commit himself over it; 3 - to reject the principle.

1 - In the Veloz-Mariana Case that opposed France and Spain in 1823 and in the Anglo-Brazilian Arbitration of 1904, to solve the problems of frontiers of British-Guyana, the arbiters applied retroactively a new customary rule. They attributed retroactive effect without posing the question of retroactivity.

There are other instances in which the international judge or arbiter delivered a dubious decision.

2 - In the case of liquidation of naval expenses in the war against Spain, the arbiter did not pronounce himself expressly on the question of retroactivity. He declared 
simply that the treaty had been applicable since its signature, thus accepting the retroactive effect of the ratification, without saying, however, if the treaty was retroactive.

In the cases of Eastern Greenland and of Minquiers et Ecréhos, the parties mutually contested the sovereignty over a territory and invoked medieval titles. The Hague Court had to make an option between the application of the modern rules of International Law concerning the acquisition of territory (retroactive application of modern Law) and the application of the Law in force in the Middle Ages.

In the two sentences it is impossible to discover which of these two points were followed.

3 - In the Alabama Case, the Arbitration court applied the Washington rules to facts happened when such rules were not in vigour. The principle of non-retroactivity was rejected by virtue of an express clause.

In the Mavrommatis Concessions Case, the Court attributed retroactive effect to Protocol XII, since the retroactivity derived from its terms and purpose:

"Protocol XII was drawn up in order to fix the conditions governing the recognition and treatment by the contracting parties of certain concessions granted by the Ottoman authorities before of the conclusion of the protocol. An essencial characteristic therefore of Protocol is that its effects extend to legal situations dating from a previous time to its own existence. If provisions were not made in the clauses of the Protocol for the protection of the recognized rights are against infringements before the coming into force of that instrument, the Protocol would be ineffective wirth regard to the very period in which the rights in question are most in need of protection. The Court therefore considers that the Protocol guarantees the 
rights recognized in it against any violation regardless of the date on which it may have taken place".

\section{Attitude of the international Judge or Arbiter in face of the non-retroactivity of conventions.}

In the Sambiaggio and Chamizal Cases, the arbiters affirmed the principle of non-retroactivity even before considering the cases of interpretative conventions and in both cases the international convention was assimilated to the national law with regard to the non-retroactivity.

In the Ambatielos Case, the Court rejected the reasoning of Greece that appealed to the theory of similar clauses :

"Accepter cette théorie serait conférer un effet rétroactif a l'article $29 \mathrm{du}$ traité de 1926, alors que l'article 32 du même traité énonce que le traité, ce qui doit signifier toutes les dispositions du traité, entrera en viguer dès sa ratification. Cette conclusion pu être contredite s'il avait existé une clause ou une raison particulière appelant une interprétation rétroactif. Il n'existe pas dans le cas présent de telle clause ni de telle raison. Il est donc impossible d'admettre que l'une quelconque de ses dispositions doive être consideré comme ayant été en viguer à une date antérieure".

The Court admits that a treaty may be retroactive if it contains "une clause ou une raison particulière appelant une interprétation rétroactf". If there is a particular clause it will express retroactivity. This exception to the principle of non-retroactivity is usually admitted; is is explained easily by the principle of autonomy of will.

The international jurisprudence recognizes that a convention may have a retroactive effect when this is expressly provided for. 
"Raison particulière appelant une interprétation rétroactif" is tacit retroactivity, that is, the retroactivity derives implicity from the treaty.

There is still the case in which the treaty has retroactive effects because of its very nature: interpretative treaties.

The European Convention on Human Rights did not have articles establishing its incompetence "rationae temporis", however "L'existence du chef d'irrécévabilité "rationae temporis" dérive cependant du principe de la non-retroactivité des traités et conventions, lequel se range parmi les principes de droit international généralement reconnus".

The Commision bases its decision concerning the retroactivity on a principle foreign to the convencion, but that imposes itself to it in the absence of an express clause to the contrary.

The non-retroactivity and the International Law Commission.

The principle of non-retroactivity was not arraigned in the International Law Commission. All the adopted and proposed texts contained such a principle with two exceptions: the express and the tacit retroactivity, inspired directly by jurisprudence and mainly by Ambatielos Sentence.

The fourth report of Sir Fitzmaurice, in section. $24 \S$ $4 .^{\circ}$, consecrated the principle of non-retroactivity:

"Unless a treaty specifically so provides, or a necessary implication to the that effect is to be drawn from its terms, it cannot give rise to retroactive rights or obligations, and there exists a presumption agains retroactivity“.

But the rapporteur observed that: "There is some danger of confusion about the subject of the retroactivity of treaties. In a certain sense, a treaty, whatever it may say, can never be retroactive, because it can never come into 
force previous to the date provided for according to its terms, or in default of clear terms on the subject, according to the principle already set ou in part I of chapter I of the code. But a treaty can of course perfectly well provide that, although it does not come into force until a certain date, it shall nevertheless, when it does come into force, be deemed to relate back in certain ways to events that have already occured. Where a treaty has retroactive effects in this sense, the obligation to apply it, or any particular provision of it retroactively can nevertheless not exist before a certain date, namely the date of the coming into force of the treaty; but that fact does not prevent the obligation that has to be applied retroactively arising when this date is reached - on the contrary, it causes it to do so. It is clear that only express terms or an absolutely necessary inference can produce such a result. The presumption must always be against retroactivity".

In 1964 was adopted art. 56 which has been art. 57 of WALDOCK's third report, with small modifications:

Art. 57 - Application of treaty provisions "rationae temporis"

1 - Unless a treaty expressly or impliedly provides otherwise, its provisions apply to each party only with respect to facts or matters arising or subsisting while the treaty is in force with respect to that party.

2 - On the termination or suspension of the operation of a treaty, its provisions remain applicable for purposes of determining the rights and obligation of the parties with respect to facts or matters which arose or subsisted whilst it was in force."

Art. 24 adopted in the project of 1966 retakes art. 56 adopted in 1964, without paragraph 2:

"Unless different intention appears from the treaty or is otherwise established, its provisions do not bind a party in relation to any act or fact which took place or any situa- 
tion which ceased to exist before the date of entry into force of the treaty with respect to that party".

The Vienna Conference adopted a text that was similar to the text proposed by the I.L.c. Art. 28 retakes the rough outline of art. 24 of 1966 , with some modifications in its formulation:

"Unless a different intention appears from the treaty or is otherwise established, its provisions do not bind a party in relation to any act or fact which took place or any situation which ceased do exist before the date of the entry into force of the treaty with respect to that party".

Several amendments were proposed, but none was accepted by the Commission. An amendment of Austria and Greece aimed at replacing the words "à moins qu'une intention différente ne ressorte pas du traité ou ne soit par ailleurs établie" by "à moins que le traité n'en dispose ainsi". The intention was to exclude the possibility of tacit retroactivity, that is, the retroactivity derived from the nature or character of the treaty.

Despite the amendments, none of the States denied the principle of non-retroactivity. The proposed amendments draw the attention to the ambiguity of some words of the r.L.C. project and to the uncertainties in the meaning of the principle. The Convention text did not dispel all doubts. This is particularly true concerning the non-retroactivity of "Jus Cogens".

The principle of non-retroactivity was consecrated in the 1969 text with reference to the very Convention by Art. 4, which had not figured in the 1966 project:

"Without prejudice to the application of any rules set forth in the present Convention to which treaties would be subject under international law independently of the Convention, the Convention applies only to treatries which are concluded by States after the entry into force of the present Convention with regard to such States". 


\section{"Jus Cogens" and non-retroactivity}

The I.L.c. considers that the rules of "Jus Cogens" do not have retroactive effects; it is clearly so declared in the commentaries of art. 50 and 61 of the 1966 project. In Art. 50 that takes into consideration the case of a treaty that is void at the time of its conclusion due to its dispositions being in conflict with an already existent peremptory norm of general international law. Art 61 considers the case of a treaty valid at the time of its conclusion, that becomes void due to the advent of a new norm of "jus congens". This words "becomes void and terminates" show clearly that in the opinion of the Commision, the advent of a new norm of "jus cogens" may not have a retroactive effect on the validity of the treaty.

Nevertless, in the case of art. 50 (Art. $71-\S 10^{\circ}$ of the Vienna Convention) that "the parties shall eliminate as far as possible the consequences of any act performed in reliance on any provisions which conflits with the peremptory norm of general international law..." It is a case of temperate retroactivity.

Regarding to the hypothesis of the advent of a new rule of "Jus cogens" (Art. 61) art. $70 \S 20^{\circ}$ says that "The termination of the treaty:

b - does not affect any right, obligation or legal situation of the parties created through the execution of the treaty prior to its termination."

The question of non-retroactivity of ratification to the time of signature.

\section{(The North American Jurisprudence and Doctrine)}

In the case of Hylton's Lesses v. Brown, 1866, the Circuit Court delivered a decision that applied the rule of retroactivity. This was the first enunciation and application of a 
doctrine that would be fostered more and more in the United States and would influence some European writers.

A plaintiff brought an action for ejectment, claiming under a lease from Joseph Griswold, made in 1789. The defendant answered that the property in question has been regularly forfeited under an act of attainder in 1778 in accordance with Pennsylvania's Laws, and after some conveyances he had been the owner since 1780 . The defendant pleaded also that any irregularity in the acts of attainder was healed by an act of Pennsylvania Legislature of January 31 st, 1783, which declared that "no misnomer or mistakes in name, addition or description, in the proclamations issued by the Executive requiring persons to surrender themselves on pain of being attainded of high treason should avail to enable heirs, to recover estates seized and sold as forteited".

The plaintiff alleged the invalidity of this act, on the ground that it was in conflict with a treaty between United States and Great Britain for preliminary articles of peace signed on November 30 th, 1782, and which was to come into force when the treaty of peace had been concluded between Great Britain and France.

On January 20 th, 1783, the Franco-British articles of peace were signed and ratified on February 3rd of the same year. Did these articles come into force on January 20th or on February 3rd, so as to bring the British American treaty into force on either date? If the British-American treaty came into force on January 20th (signature), the act of 1783 was void because it was passed after it.

The resolutions of the Court were the following:

"It is contended (by the defendant) that this treaty can only be considered as made on the 3rd of February following, when it was ratified; and in support of this opinion, it is stated that, by its terms, it was suspended till ratification. No evidence of this has been given; and from the subsistence of these preliminary articles ... there is no reason 
to supose that this was the case ... But even if this were the fact, as to this treaty; .. we do not think it would affect the case, because, when ratified, the treaty would relate back to the signing. The ratifications is nothing more than evidence of the authority under which the ministers acted ... I am constrained, then, to say, that the terms of peace were agreed on between Great Britain and France, on the 20th January, and consequently that the contingency, on which the treaty between Great Britain and the United States was to take effect, happened on, and was binding upon, the two nations, from that day, if no sooner".

"Upon the whole, then, it is the opinion of the court, that the law of 31st of January, 1783, in posterior to the treaty of peace, which is the supreme law".

The Court invoked the authority of Grotius, VATTEL and Martens in order to support the existence of the rule of retroactivity of ratification to the date of signature. Of the three, only MarTENs had expressed a definitive opinion on the matter:

"Of treaties in general. Anything that has been promised by the chief or his agent beyond the limits of the authority with which the State has entrusted him, is at most no more than a simple promise ("sponsio") ... On the contrary, everything that has been stipulated by an agent in conformity with his full powers ought to become obligatory for the State from the moment of signing without waiting even for a ratification. However, not to expose the State to the errors of a single person, it is now become a general maxim that public convention do not become obligatory till ratified".

It seems nevertheless, that the agency theory exerted a strong influence in formulating such a decision. To the generality of XVIJ century's internationalists, the obligatory strengh of a treaty consubstantiates itself at the moment of its signature by the plenipotentiaries. This resulted from 
the application to the full powers of the privatist rules about the mandate.

In despite of its necessity, the formality of ratification add nothing to the validity of the treaty, that exists and obliges since its signature. It would be only a confirmation by reason of courtesy and regularity of the international relations.

In the case of the United States v. Arredondo, 1832, the Supreme Court of the United States added a limitation to the rule laid down in Hylton's Lesse v. Brown, it were to be deemed as operating retroactively as to the date of signature only in so far as the treaties deal with rights or oblifations of the parties as States, but not as the affected private rights:

In the cases of the United States v. Reynes and Davis v. Police in 1850 , the doctrine asserted in Hylton's Lessee v. Brown was approved by the Supreme Court of the United States. This Court reaffirmed the limited rule of retroactivity laid down in the Arredondo Case, in 'Haver v. Yaker'.

The principle of retroactivity has been affirmed by American Courts in others cases.

This ouctrine was stated by Moore as follows:

"A treaty is binding on the contracting parties unless otherwise provided, from the date of its signature, the exchange of ratifications having, in such case, a retroactive effect, confirming the treaty from that date".

During the second part of the last century, Wheatom stated that "every treaty is binding on the contracting parties from the date of its signature, unless it contains an express stipulation to the contrary. The exchange of ratifications has retroactive effect, confirming the treaty from its date".

The article 421 of the Bluntschli draft adopts the rule of retroactivity (it is the only code on treaties in doing that) : 
"Cette règle est l'expression d'un usage reçu par les nations. Elle se fonde sur le fait qu'au moment de la signature du traité, la position respective des états est définitivement regularisée; la ratification, qui survient quelquer jours plus tard, a seulement pour but de lever le dernier obstacle à l'exécution immédiate du traité. La ratification doit donc être considerée comme ayant eu lieu, de la volonté des parties, à l'instant de la signature du protocol définitif".

Among the authours of the last century and begining of the present that support the doctrine of retroactivity, are: Calvo, Mérignhac, Twiss, Woolsey, Wharton, Taylor, Hershey, Hyde, and Grandall.

Less than a century ago, due to the generic acceptance, MARTENs said the doctrine of retroactivity was "universally recognized and accepted as an axiom by all authors who have written on international law".

Reaction to the American doctrine.

GEFFGKEN considered the principle of retroactivity as unacceptable, unless there was a contrary clause in the treaty. Louter declared that the retroactivity doctrine held by the older authors was "the logical result of an erroneous conception which regards ratification as a suspensive condition of the obligatory character of a treaty rather than an essencial element". Other authors that adopt the same view: Fauchille, Hoijer, Despagnet, Piédelièvre, Teltsik, Strupp, Blociszewski, Lizt, Gidel and Morellet.

The protocol of the Congress of Berlin of July 1878, said that: "Le Congrès considère que ce sont les ratifications et non seulement la signature qui donnet aus traités valeur définitive".

Article 8 of the Havana Convention on Treaties of 1928 declares that "treaties shall become effective from the date of exchange or deposit of ratification, unless some 
other date has been agreed upon through an express provision". The following authors accept this doctrine: Oppenheim, Brierly, McNair, Basdevant, Dupuis, Anzilotti, Cavaglieri, Fiore and Gemma.

The Jurisprudence of the United States was contradicted by other countries.

The English High Court of Justice rejected the argument that the ratification of the Treaty of Versailles -- January 10 th, 1920 - operated retroactively back to the date of signature - June 28th, 1919.

In the case of Cominelli v. CAPELLI, the Italian Court of Cassation decided that the full international effects of the Treaty of St. Germain had begun on the date of the exchange of ratifications and not from the date of signature.

The Supreme Court of Poland in Schrager v. Workmen's Accident Insurance Institute for Moravia Silesia and in Gospodarstwa Krajowega v. Czyzewics, alleging considerations of equity or good faith adopted the rule of retroactivity. But these decisions do not seem to approve retroactivity as a general principle.

Normally the decision on international arbitration courts have not accepted the rule of retroactivity. Nevertheless in the Chilean-Peruvian Accounts - $1875-$, the arbiter declared the treaty operative from the signature, but he did not make any reference to an international practice in this sense.

The umpire in the Sambiaggio Case (1902) considered that treaties should not be interpreted to operate retroactively unless the same treaty so provided.

Considerable discussion about the principle of retroactivity was made in the Iloilo Claims, before the British-American Claims Tribunal. Great Britain made claims against the United States concerning a property destroyed at Iloio, by the Filipinos in February, 1899. Britain accused the United States of being responsible for the maintenance 
of order in Iloilo as from the date of signature of the treaty of Paris (December 10th, 1898), in which Spain surrended the Philippine Islands to the United States. The ratifications of this treaty were exchangedon April 11th, 1899, after the disturbances contemplated by the claims.

The United States answered that the destruction of property had happened at a time when Iloilo was still Spanish territory, because the sovereignty over the archipelago passed to the United States on April 11th, 1899, date of the exchange of ratifications.

The tribunal laid that "de jure" there was no sovereignty over the island until the treaty was ratified, thus accepting that the treaty was effective on the date of the exchange of ratifications and not on the date of signature.

The PcIJ did not make direct pronouncements on the question of retroactivity of treaties.

The Harvard Convention which aimed at "setting forth what is deemed to be the existing law of the treaties" in its article 11, codified the winning doctrine:

"Unless otherwisse provided in the treaty itself, a treaty which comes into force subsequently to the time of signature shall not be deemed to have effect as from the time of signature".

This article is a total rejection of the rule of retroactivity. The treaties, however, may operate retroactively if they so expressly provide.

Mc NAIR stated that "the rule of retroactivity can no longer be accepted".

The Vienna Convention seems to consider only the non-retroactivity of provisions of the treaty back even to a time antedating the conclusion of the treaty. Combining nevertheless, syllogistically some articles of the Convention, we will see that it implicitly consigned also the non-retroactivity of ratification to the date of signature. 
Acoording to article 28, the provisions of the treaty become binding at the date of its coming into force. Number 2 of article 24 declares that the treaty comes into force when there is consent of the States that have participated in the negotiations. The consent is expressed by the ratification, when it is foreseen in the treaty, in the negotiations or in the full power (article 14) or by signature only if it is so provided by the negotiations or by the full powers (article 12). Hence the dispositions of treaty become binding by the ratification or by signature (when the ratification is not required).

We may now replace the final part of art. 28 "the date of the entry into force of the treaty with respect to that party" by "the date of ratification or signature (when the ratification is not required)" and we will note clearly the prohibition of the retroactivity of ratification to the date of signature.

\section{Bibliography.}

1. BRIGGS, H. W., "Reflections on Non-Retroactivity of Treaties" in Revista Española de Derecho Internacional, 1968, p. 320.

2. Draft Convention on the Law of Treaties (Text with coments) in American Journal of International Law, vol. 29, Supplement, p. 657.

3. Holisoway. K., Modern Trends in Treaty Law Stevens Oceana, London, 1967.

4. JoNEs, J. M., The Retroactive Effect of the Ratification of Treaties in American Journal of International Law, vol. 29, 1935 p. 51.

5. Mc NaIR, The Law of Treaties, Clarendon Press, Oxford, 1961.

6. QuAdrI, R., Diritto Internazionale Pubblico, Priulla Editore, 4. ${ }^{\mathrm{a}}$ Ed. Palermo.

7. TAVERNIER, P., Recherches sur l'application dans le temps des actes et des règles' en droit international public, Pinchon et Durand-Auzias, Paris, 1970. 